\title{
PLACE ATTACHMENT BASED URBAN REFORM AS TOURISM POTENTIAL OF KAMPONG SEMUT
}

\author{
Putu Bulan Ratna Anggraeni ${ }^{1}$, Fery Asta Wibowo ${ }^{2}$ \\ ${ }^{1,2}$ Department of Architecture, Sepuluh Nopember Institute of Technology, Jalan Raya ITS, Surabaya, Indonesia \\ justbulan@gmail.com ${ }^{1}$
}

How to cite (in APA style):

Anggraeni, P.B.R., Wibowo, F. A., (2019). Place Attachment Based Urban Reform As Tourism Potential Of Kampong Semut. Undagi: Jurnal Ilmiah Arsitektur. 7(2), pp.145-152.

\begin{abstract}
Tourism activities can never be separated from the history of a city and the influence of the development of the city itself. Aspects of tourism are very dependent on culture and public understanding of a tourist attraction in a city. Kampong Semut is one of the historical relics of the city of Surabaya which has the potential to become a tourist facility. The potential is due to the fact that Kampong Semut has a potential in the form of community attachment to the location. The community's attachment to a Kampong Semut, changing the form and function of the village itself from a large-scale activity center to an urban village that is not conserved. The purpose of this study is to understand more deeply the place attachments that exist in Kampong Semut and see what potential can be developed back into a tourism potential to be able to return the Kampong Semut to its former glory. This study uses an urban analysis method to see the shape of the city and the layers of the city in Kampong Semut to see the changes brought by the people in Kampong Semut to the place attachments.
\end{abstract}

Keywords: community; urban village; place attachment; urban analysis

\section{INTRODUCTION}

Kalimas River is a river that plays an essential role in forming settlements or villages in the city of Surabaya. Same as the beginning of the center of other island towns, Surabaya City also started a formation that began from the river's edge. This matter is because the river is the most comfortable place to live, such as drinking water, bathing, garbage disposal, and transportation facilities that utilize river flow. Therefore, settlements on the banks of the river are usually old villages inhabited by generations. One of the ancient communities on the Kalimas River is Kampong Semut.

Kampong Semut in Bongkaran Village located at the east bank of the Kalimas River, which is dominated by the housing function. The eastern part of Kampong Semut is bordered by Pengampon Village, while in the south it is bordered by Jagalan Village. In the northern part of the village, there is a station that is now a cultural heritage building, Surabaya Kota
Station, better known as Semut Station. This place is a historic place that was built in 1878 and has since influenced the living conditions and the surrounding environment, especially in the Kampong Semut itself.

Kampong Semut is one of the villages closest to the city center, where inside the city center consists of various ethnic groups, both Javanese, Chinese, and Arabic. As one of the old communities in the city of Surabaya, it has its history and characteristics. The people who lived and grew up in Kampong Semut for generations defined the village environment as a form of their home. Therefore, research on the shape and structure of space in the Kampong Semut is needed to find out the implications of place attachment that occur in more depth. In connection with this, humans will have a strong emotional bond to a place if there is an intense experience or interaction (Ujang, 2012). If there is no experience, there will be no place or space. Experience can be felt directly by physically 
contacting the situation, or indirectly, for example, hearing stories from other people.

According to Brown, Altman, and Werner (2012), place attachments are behavioral, cognitive, and affective ties between individuals or groups that develop positive relations to their environment. Furthermore, according to Darjosanjoto (2015), place attachment is a condition of attachment between humans and the context in which they live. The relationship is formed and makes them feel at home and really like an environmental condition. So, through the two statements, concluded that the satisfaction felt by the human group to their place of residence creates a place attachment. Various factors affect this condition, such as economic and social. Both of these factors can influence a person's decision to continue to choose to stay or to decide to move from a place to a specific area. Besides, social factors such as human resources and natural resources that are genuinely attached will make sense of attachment between humans and a place stronger. Every human being or group of humans has a preference or tendency to stay in a specific condition (Dahl and Sorensen, 2009).

Scanell \& Gifford (2010) compose an integrated place attachment structure through a three-dimensional framework, namely: human - psychological process - place, each of which is different and intertwined. The form below can describe the Framework or structure of the attachment:

- The social dimension refers to the individual or collective meanings.

- The psychological aspect includes the influence, observation, and behavioral component of attachment.

- The place dimension provides attachment to the characteristics of the place, including the base of space, type of space, and social excellence or physical elements.
According to references by Lee et al (2012), Ramkissoon (2016), and Veasna et al. (2013), there are several terms used to describe behavior related to place attachments. In some parts, namely place dependence, place identity, place effect, and set social bonding can conceptualize place attachments. The four pieces of the place attachment reflect the various feelings of individuals associated with the environment when they live in a situation. In places that have cultural values, there are at least three categories in the place attachment dimension, namely:

- Social aspects, namely ties with family and heredity. Human groups have a view of the place where they live as a right place through the reflection of attachment, dependence and positive place identity in facilitating their social integration (Dempsey et al., 2011). Bond refers to human relations with the place and shows the identification of history in home, family, and community. This matter usually happens to traditional villages that have been occupying a position for a long time.

- Material aspects consist of ties through land loss and economic relations. In functional needs, there are opportunities to participate in meaningful activities that give identity to individuals and groups to foster attachment to places. Following the opinion of Moulay et al. (2017), the longer people stick to a situation, the stronger the attachment becomes. The primary form of bonding through the process of land loss is the breakdown of the previous type of bonding. The method of land loss can occur in various ways, such as resettlement due to natural disasters or the development of urban areas. Land use formed economic ties, such as ownership of land as a source of life. Bonding to a place can also occur on the property, not only on a house or 
building. Purchase of the property will make an individual declare the ground as his place.

- Ideological aspects consist of cosmological ties, ties through pilgrimage, and bonds through narration. Cheshmehzangi (2012) argues that historic cities provide unique physical features and meanings that contribute to placing the identity of a place. The uniqueness is limited to the ideological aspects of urban space construction, which contribute to historical significance. Cosmological ties show the beliefs of local myths and their relationship to a landscape. This matter can be in the form of land that is sacred by the community, considered as a natural hue for ancestors and God bonding through pilgrimage and participation in a traditional ceremony. This bond can evoke moral values, common sense, and cosmological meaning through memory, travel, and experience of places. Another form of bonding is bonding through narrative tales or legends. Narratives about naming particular places or family history and politics form these bonds.

\section{METHODOLOGY}

The urban space analysis technique used in this study is the diachronic reading method. The purpose of this study is to understand the place attachments that occur in Kampong Semut. The review is carried out from the micro-segment and macro-segment. The micro-segment is in the form of a house, and the macro section is in the way of a whole village structure. So to obtain these objectives, the targets set will be examined, namely:

- Identifying the development of population compaction and road structure
- Identifying the specific characteristics of the area architecture related to the sociocultural community, and

- Identifying three categories in the place attachment dimension as the stage of formation place identity.

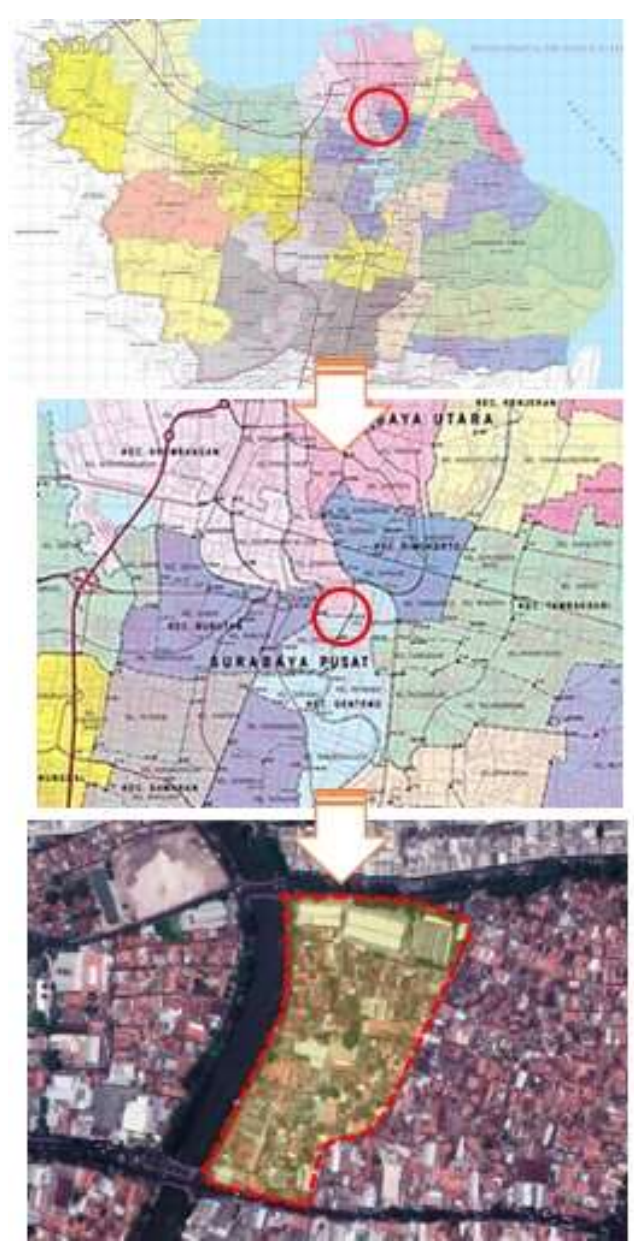

Figure 1. Orientation of Kampong Semut (Source: Author, 2019).

\section{RESULTS AND DISCUSSION}

Kampong Semut in Bongkaran Village is a village on the east bank of the Kalimas River, which is dominated by housing functions. Pengampon Village borders the eastern part of Kampong Semut while Jagalan Village borders the southern region. In the northern part of the village, there is a station that is now a cultural heritage building, the Surabaya City Station or better known as Semut Station. This place is a 
historic place that was built in 1878 and has since affected the living conditions and the surrounding environment, especially in Kampong Semut itself.

Kampong Semut, which is the location of the study, is located in the District of Pabean Cantian, Kelurahan Bongkaran. The existence of a land transportation center around it, namely Surabaya Kota Station (now Semut Station) affects the formation of Kampong Semut. Surabaya City Station in the 1870s the idea of establishing the Semut Station began to be heard in the Dutch colonial government. So that at that time was determined through the Staatsblad Law No. 141 or according to the calendar of the Dutch East Indies Government 6 April 1875 where the decision contained the construction of a railroad network in Java. In 1875 the development of the railroad line with funding from the Dutch East Indies Government began. The construction of Surabaya Kota Station occurred when the Surabaya-Malang and Pasuruan railroad lines started around 1870. The purpose was to transport agricultural products from the interior of East Java, especially from Malang, to the Port of Tanjung Perak which also began to stand around that year.

Increased trading activities in the city of Surabaya sparked the construction of Surabaya City Station. This matter is related to the urban development movement during the reign of Governor-General Daendels. Daendels carried out the installation of transportation facilities to serve the city of Surabaya, which is still a fortress city by Prince Willem Frederick Hendrik's mandate. The development of Surabaya as a fortress city created ethnic restrictions, including Javanese, Madurese, Buginese, and Balinese groups. This matter causes people who live in the city must get out of the town first before getting a fortress. In the urban area are the Dutch, Chinese, Arabs, and Moors. This matter caused the indigenous community only to have the choice of living around the fort walls or returning to the village. The development of the city of Surabaya, which began to pay attention to the natives started between 1830 and 1860 .

Furthermore, the government began demolition of the city and caused the city of Surabaya to experience structural development to the south. In 1905, the railroad to appear in the city of Surabaya, this railroad line connecting Surabaya with Pasuruan and Malang. This matter is the beginning of the development of the Kampong Semut area in terms of the development of population compaction, road structures, and building architecture related to place attachments.

1. Development of Population Compaction and Road Structure

The development of the city of Surabaya, which began to pay attention to the natives started between 1830 and 1860 . The city of Surabaya to experience the growth of the structure to the south. In 1905, the railroad began to appear in the city of Surabaya, this railroad line connecting Surabaya with Pasuruan and Malang. Map documentation in 1825 is the most extended map found and provides information that at that time, Kampong Semut was still in the form of forests and plantations (see Figure 1). The map shows that the area has one permanent building. The name of the village itself is still part of the Pengampon and Pandean regions. The structure of the road is always straightforward. The route follows the edge of the river and the existing bridge on Kalianyar. There is no other way at all because there is no settlement. 


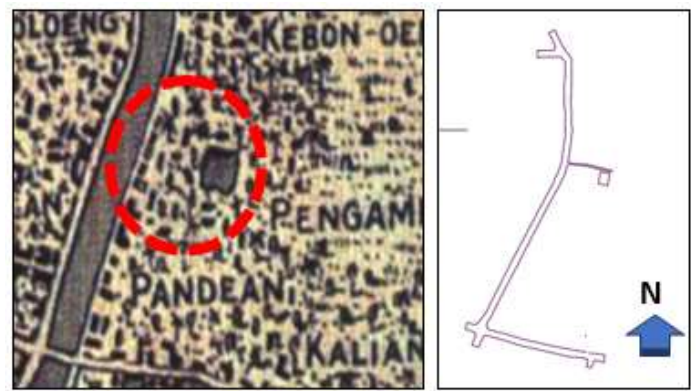

Figure 1. Kampong Semut Map 1825 (Source: Author).

On the map in 1866, the government began to build residential buildings and warehouse buildings (see Figure 2). The building appeared at the crossroads of the Jagalan area in the south which is now the Sasana Bhakti school building. Then also can be seen the emergence of settlements and the first road branch, Jalan Semut 4. There are at least four houses that stand as the embryo of the village. The right to build a home is indeed inseparable from the use of vervreemdings-verbod rules which strengthen the reasons for the indigenous people to own their land. At that time, the natives bought more land in preparation for being passed on to their successors. Then it can be seen that there is a distance between one house and another with the hope that their children can stay closer.

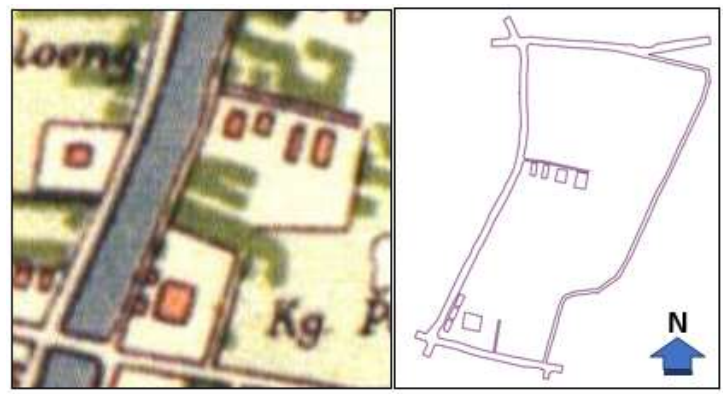

Figure 2. Kampong Semut Map 1866 (Source: Author).

Based on its history, the government established the Surabaya City Station when the Surabaya-Malang and Pasuruan railroad lines began operating around 1870 . It aims to transport crops and plantations from the interior of East Java, especially from Malang, to the Port of Tanjung Perak which also began around the year that. The official station building was operational on May 16, 1878. With the increasing use of trains, on November 11, 1911, the station building underwent expansion to its present form. The existence of this station has an essential influence on the life and development of the population in Kampong Semut.

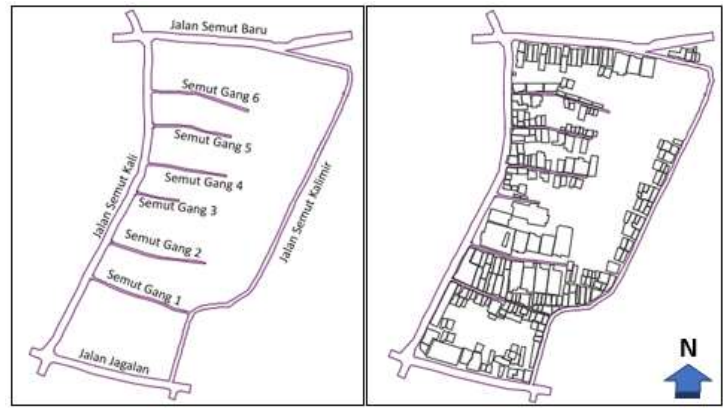

Figure 3. Kampong Semut Map 1900 (Source: Author).

The 1900 map shows a rapid development over the previous 30 years (see Figure 3). Growing road branches as access road settlements that began to pack and form Kampong Semut. The road branches include Jalan Semut Gang I, II, III and IV. The community makes sequential road naming. The main road is the western part of the village that follows the riverbank. Branching leads eastward. The first compaction is on the west side, the regions closest to the river. Over time the solidified towards the east. Until 2017, Kampong Semut has been compacted to become a crowded village (see Figure 4). Buildings grow huddled together. Communities make roads without planning and only aim to make attainments to their respective homes. This matter results in an irregular environmental road structure. The way formed is also only possible for two-wheeled vehicles. 


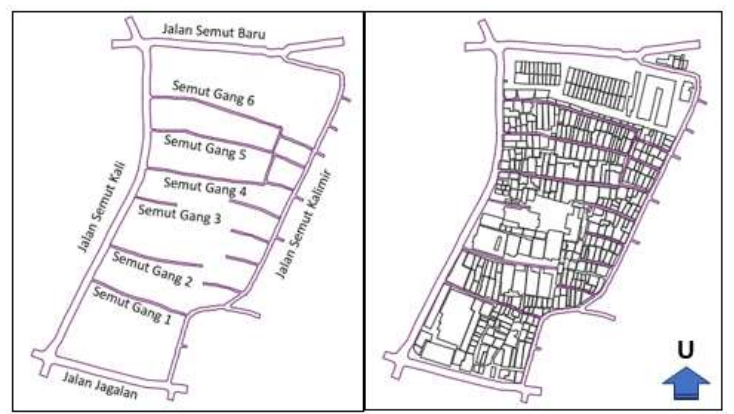

Figure 4. Kampong Semut Map 2017 (Source: Author).

2. Special Characteristics of Regional Architecture Related to Social and Cultural Communities

Place attachment refers to the formation of one's inner bond with a place such as a residential environment (Altman \& Low, 1992). Theoretically, one of the determinants of place attachment is residential-satisfaction (Bonaiuto et al., 1999; Bonaiuto et al., 2004). Various things can work for Residentialsatisfaction, one of which is by implementing a culture of residence by the beliefs/culture adopted. One of them is ethnic and ethnic factors. The culture of the Javanese and ethnic Chinese population dominates the Kampong Semut and gives a unique characteristic to the architecture in the village.

Residential buildings that are mostly found and are old buildings in Kampong Semut use the typical Javanese architecture type of building especially "Suroboyoan," which has the following characteristics:

- Doro Gepak Style Roof

The house with original Surabaya architecture has a roof called Doro Gepak. This roof is a roof shaped like a pigeon flying in flapping wings (see Figure 5). This Doro Gepak-style roof is known for its natural way of making it because of its simple design. The roof with this model is also known as cheap. Doro Gepak roof has a lot of air holes, making it suitable for lowwalled houses.

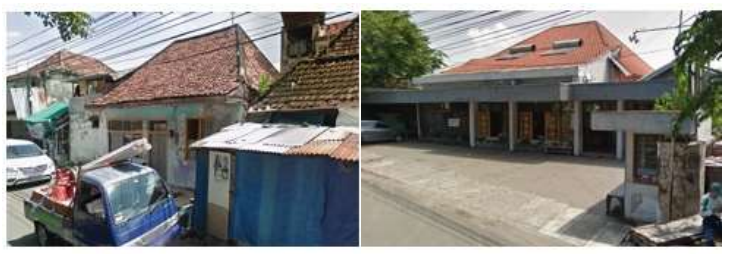

Figure 5. Doro Gepak Style Roof (Source: Author).

- Low Wall

Unlike the houses of the Dutch people at that time who did have homes with high walls. The height of the wall with the original design of Surabaya is only about 12 to 14 meters, and generally, the building with the unique design of Surabaya has only one other floor.

- Narrow House Terrace

Similar to the character of Surabaya and egalitarian and upholding kinship, the homes of Surabaya residents in the past never used fences, tending to be close together to avoid distance between neighbors (see Figure 6). With a veranda that is not too big, it is different from Portuguese and Dutch-style houses which do have a wide terrace.

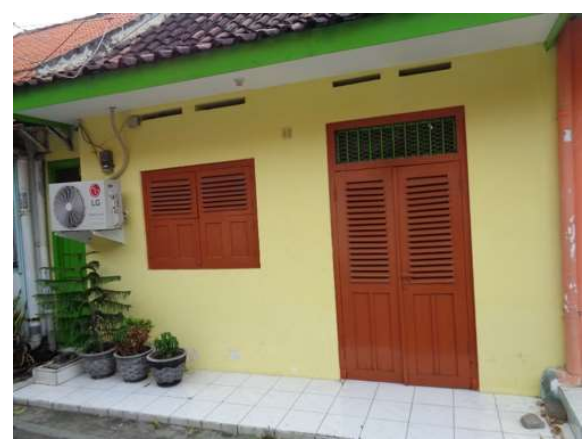

Figure 6. Narrow House Terrace (Source: Author).

However, being aware of the condition of the villages that are close to a large station makes this area vulnerable to crime, especially theft in the town. Because seeing the amount of crime, the buildings are trying to make a physical change to the structure to provide more protection. One of the efforts is to build a fence on the porch (see Figure 7). This matter can be 
seen very much happening in the Kampong Semut residence.

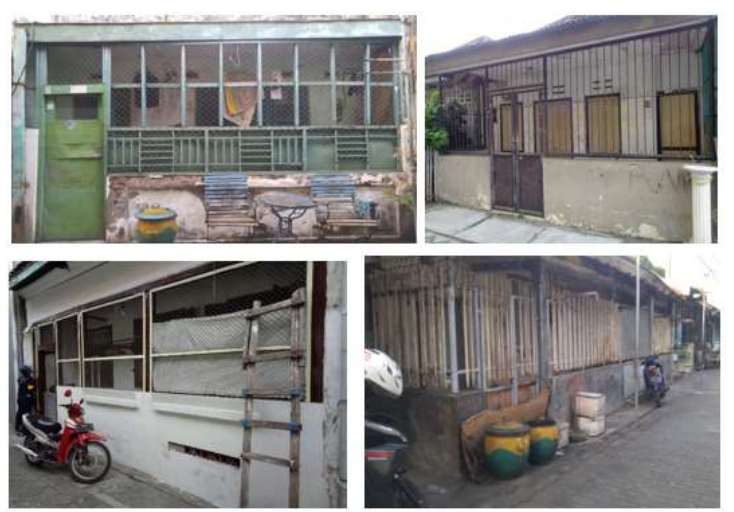

Figure 7. Fencing on The Porch of The House (Source: Author).

The following is the identification of the place attachment of Kampong Semut:

- Social aspects: ties with family and lineage lineages. This bond refers to the human relationship with the place, the identification of history in the home, family, and community. Most elderly respondents choose to spend their old age in Kampong Semut. This matter is because the building they occupy is a legacy from parents who have historical value for their lives. This kind of thinking makes the social aspect of attachment to a place stronger due to the process of surrendering a "place" to the next generation.

- Material points: the process of land use for personal needs. Material elements in the form of transferring the function of land as a particular interest, forming an economic bond from the use of land that becomes the "property" of individuals. Based on the desire to be able to make ends meet, ownership of an area will make the individual declare the land as his "place."

- Ideological aspects: cosmological views and myths of local people and their relationship to a landscape in Kampong Semut. The road structure, which in Kampong Semut still adheres to the beliefs of Ancient Java that use the mandala orientation. Can be seen the direction of the majority of houses there facing north and south.

\section{CONCLUSION}

Surabaya City's dependence on rivers had begun in the pre-colonial period. The early Surabaya people relied on Kalimas for activities that needed water; this gave rise to the potential for the development of areas around the river. Kampong Semut, which is the location of the study, has a connection with the river and implements a transportation equipment change system. The purpose of the construction of the railway line and the Semut Station is as a mode of transportation for transporting crops and plantations. Nearby land transportation centers, namely Surabaya Kota Station (now Semut Station) influence the formation of Kampong Semut. Surabaya City Station in the 1870s the idea of establishing the Semut Station began to be heard in the Dutch colonial government. Semut village, as one of the old cities and has a strong place attachment and must be maintained, has a lot of potential to become a historical tourist area. This potential is due to the many residential buildings in Kampong Semut that are old buildings. The building uses a type of Javanese architectural construction, especially "Suroboyoan," which has characteristics including Doro-style roofs, low walls, and narrow terraces. However, to become a tourism area, Kampong Semut needs village development planning to be more organized and aesthetically so that it becomes a habitable place that is easy to be transformed into a tourist village.

\section{REFERENCES}

Altman, I. \& Low, S. (1992). Place attachment, $1^{\text {st }}$ edition. Plenum Press, New York.

Bonaiuto, M., Aiello, A., Perugini, M., Bonnes,
M., Ercolani, A. P. (1999). 
Multidimesional Perception of Residential Environment Quality and Neighbourhood Attachment in the Urban Environment. Journal of Environmental Psychology, 19(4). P.331-352.

Bonaiuto, M., Bonnes, M., \& Continisio, M. (2004). Neighborhood Evaluation within A Multi-place Perspective on Urban Activities. Environ. Behav., 36. P.41-69.

Brown, B.B., Altman, I., \& Werner, C.M. (2012). International Encyclopedia of Housing and Home: Place Attachment, Elsevier, Amsterdam.

Cheshmehzangi, A. (2012). Identity and Public Realm. Procedia-Social and Behavioral Sciences, 50. P.307-317.

Darjosanjoto, E.T.S. \& Nugroho, S. (2015). Design Criteria for Open Space at the Riverbank Area in Kampung Wonorejo Timur. International Journal of Education and Research, 3(4). P.417-426.

Dahl, M.S. \& Sorenson, O. (2009). The Embedded Entrepreneur: European Management Review, Palgrave Macmillan.

Dempsey, N., Bramley, G., Power, S. and Brown, C. (2011), "The social dimension of sustainable development: defining urban social sustainability", Sustainable Development, Vol. 19 No. 5, P.289-300.

Lee, J., Kyle, G., \& Scott, D. (2012). The mediating effect of place attachment on the relationship between festival satisfaction and loyalty to the festival hosting destination. Journal of Travel Research, 51(6). P.754-767.

Moulay, A., Ujang, N. \& Said, I. (2017). Legibility of Neighborhood Parks as A Predictor for Enhancedsocial Interaction Towards Social Sustainability. Cities 61 . P.58-64.

Ramkissoon, H. (2016). Place Satisfaction, Place Attachment and Quality of Life: Development of A Conceptual Framework for Island Destinations. Sustainable Island
Tourism: Competitiveness and Quality of Life. P.106-116.

Scanell, L. \& Gifford, R. (2010). Defining Place Attachment: A Tripartite Organizing Framework. Journal of Environmental Psychology, (30). P.1-10.

Ujang, N. (2012). Place Attachment and Continuity of Urban Place Identity. Procedia - Social and Behavioral Sciences, 49(2). P.156-167.

Ujang, N. (2016). Affective Perception of Place: Attachment to Kuala Lumpur Historical Urban Places. Proceedings of Open House International, 41(2). P. 95101.

Veasna, S., Wu, W., \& Huang, C. (2013). The Impact of Destination Source Credibility: The Mediating Effect of Destination Attachment on Destination Image. Tourism Management, 36. P.511-526. 